Florida International University FIU Digital Commons

\title{
Where Are All the Bonefish? Using Angler Perceptions to Estimate Trends of Bonefish (Albula vulpes) Decline in South Florida
}

Emily K.N. Kroloff

Florida International University, ekrol001@fiu.edu

DOI: $10.25148 /$ etd.FIDC000799

Follow this and additional works at: https:// digitalcommons.fiu.edu/etd

Part of the Aquaculture and Fisheries Commons, Environmental Studies Commons, and the Other Anthropology Commons

\section{Recommended Citation}

Kroloff, Emily K.N., "Where Are All the Bonefish? Using Angler Perceptions to Estimate Trends of Bonefish (Albula vulpes) Decline in South Florida" (2016). FIU Electronic Theses and Dissertations. 2541.

https://digitalcommons.fiu.edu/etd/2541 


\title{
FLORIDA INTERNATIONAL UNIVERSITY
}

Miami, Florida

WHERE ARE ALL THE BONEFISH?

USING ANGLER PERCEPTIONS TO ESTIMATE TRENDS OF BONEFISH

(ALBULA VULPES) DECLINE IN SOUTH FLORIDA

\author{
A thesis submitted in partial fulfillment of the \\ requirements for the degree of \\ MASTER OF SCIENCE \\ in \\ ENVIRONMENTAL STUDIES \\ by \\ Emily Kathryn Nneka Kroloff
}


To: Dean Michael R. Heithaus

College of Arts, Sciences and Education

This thesis, written by Emily Kathryn Nneka Kroloff, and entitled Where Are All the Bonefish? Using Angler Perceptions to Estimate Trends of Bonefish (Albula vulpes) Decline in South Florida, having been approved in respect to style and intellectual content, is referred to you for judgment.

I have read this thesis and recommend that it be approved.

$\begin{array}{r}\hline \text { Qing Lai } \\ \hline \text { Jennifer Rehage, Co-Major Professor } \\ \hline \text { Joel Heinen, Co-Major Professor }\end{array}$

Date of Defense: July 8, 2016

The thesis of Emily Kathryn Nneka Kroloff is approved.

Dean Michael R. Heithaus
College of Arts, Sciences and Education

Andrés G. Gil

Vice President for Research and Economic Development and Dean of the University Graduate School

Florida International University, 2016 


\section{DEDICATION}

I dedicate this thesis to my mom, who was a constant source of support and encouragement throughout my entire graduate school process. Without her inspiration I would not be where I am today. 


\section{ACKNOWLEDGMENTS}

First and foremost, I want to thank my major advisor Dr. Joel Heinen who has been a constant source of support, good advice, and humor throughout my time at Florida International University. His guidance as an academic advisor and mentor really facilitated my personal growth and helped to affirm my life goals. Dr. Heinen's belief in my capabilities was a truly invaluable tool in my success. I would also like to thank Dr. Jennifer Rehage for co-advising me and giving me the opportunity to work on such an interesting research project as well as granting me with a research assistantship. Lastly, I want to thank Dr. Qing Lai who was key in helping come up with vital components of my survey design as well as contributing all of his time to help with statistical analysis. His statistical consulting has been crucial throughout my research process.

I am very thankful for Barbara Pazos, Ana Guzman, Alejandro Lozano-Garcia, Kat Braddock and Jessica Lee for their friendships, knowledge and support when I needed it most. I would also like to thank Bryan Garcia and the entire Rehage lab including Jesse Blanchard, Vanessa Trujillo, Greg Hill, Christine Beck, Ross Boucek, Cody Eggenberger and Rolando Santos for all their help and advice.

Thank you to Florida International University, the College of Arts, Sciences, and Education, and the Earth and Environment department for allowing me the opportunity to pursue and complete my master's degree under their affiliation. I would finally like to thank the Bonefish and Tarpon Trust for funding this research project which gave me the opportunity and means to purse and complete my master's degree. 
ABSTRACT OF THE THESIS

WHERE ARE ALL THE BONEFISH?

USING ANGLER PERCEPTIONS TO ESTIMATE TRENDS OF BONEFISH ( $A L B U L A$ VULPES) DECLINE IN SOUTH FLORIDA

by

Emily Kathryn Nneka Kroloff

Florida International University, 2016

Miami, Florida

Professor Joel Heinen, Co-Major Professor

Professor Jennifer Rehage, Co-Major Professor

Local ecological knowledge (LEK) is a useful method to capture environmental or resource changes when there is an absence of biological data. Since the bonefish fishery is data limited, this study aims to understand the trend of bonefish decline over the last 40 years using LEK and to assess whether varying fisher experience and fisher type would influence perception of bonefish decline. Semi-structured surveys and key informant interviews were conducted to collect LEK data. Along with perceiving an overall decline $(\mathrm{p}<0.001)$, fishers perceived a non-gradual decline that started at different points in time based on different parameters; overall quality of bonefish, size of bonefish and number of bonefish. Furthermore, there was little evidence of bias introduced through experience or fisher type. Our results suggest that the use of LEK when trying to understand population changes in a data-poor ecological system can be valuable and beneficial when handled correctly. 


\section{TABLE OF CONTENTS}

CHAPTER

PAGE

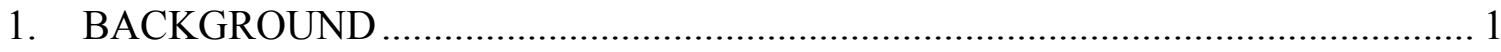

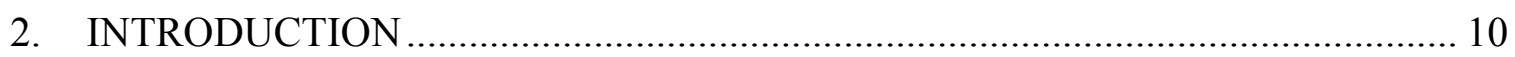

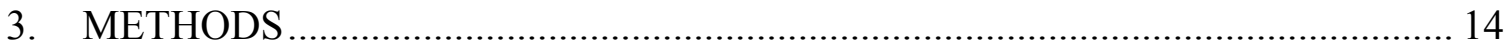

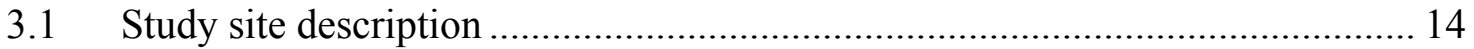

3.2 Interview approach and survey design .................................................. 15

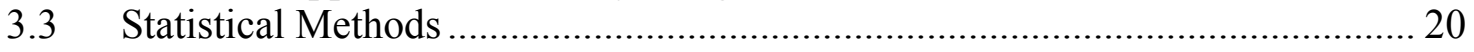

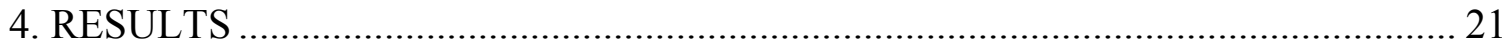

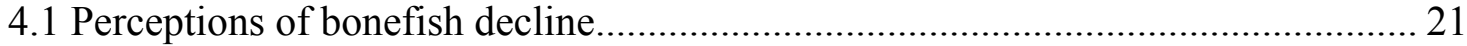

4.2 Perceptions of bonefish decline related to fisher experience .............................. 23

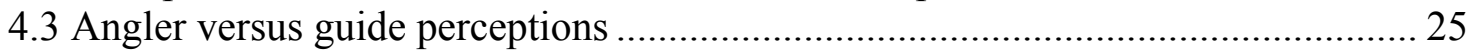

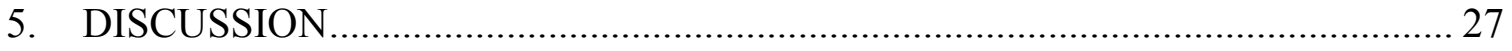

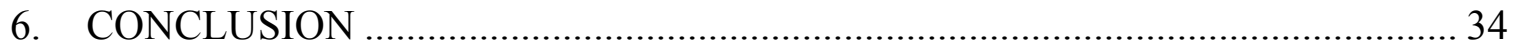

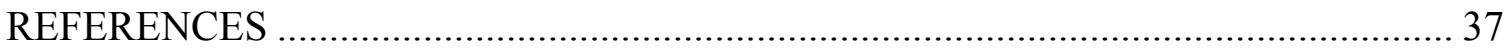

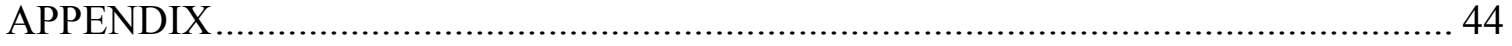




\section{LIST OF FIGURES}

FIGURE

PAGE

Figure 1. Timeline of anthropogenic and natural alterations that have been linked to changes in the Florida Bay (adapted from various sources; (Fourqurean and Robblee, 1999), (Light and Dineen, 1994), (Porter, 2001))....................................

Figure 2. Management and regulation jurisdictions of various agencies in South Florida (NOAA, 2013) .................................................................

Figure 3. Trend of bonefish decline is plotted from the mean scores rated by respondents on the overall quality of the bonefish fishery from 1975 to 2015. Respondents were asked to rate their bonefish fishing experience from 1 to 5 over the time they have been fishing for bonefish in South Florida. Sample size in the figure is based on the respondent sample size however, the trend is based on total response sample size. See methods for further explanation.

Figure 4. Overall bonefishing quality can be divided into two factors, number of bonefish caught and size of bonefish caught. When quality is divided into these two factors, the decline trend looks different. Respondents were asked to rate from 1 to 5 how number and size of bonefish changed from when they started fishing for bonefish in South Florida. Sample size in the figure is based on each respondent; however, the trend is based on total response sample size. See methods for further

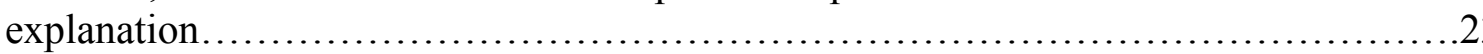

Figure 5. Angler experience plotted by time (a. overall quality parameter, b. size parameter) Error bars are based on standard error..................................

Figure 6. Comparison of perceived bonefish decline trend between fisher type (guides

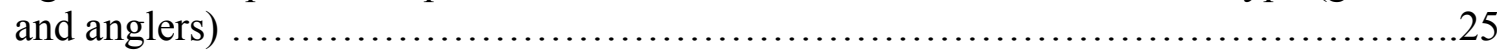

Figure 7. Angler and guide perceptions of the major causes for bonefish decline (a.

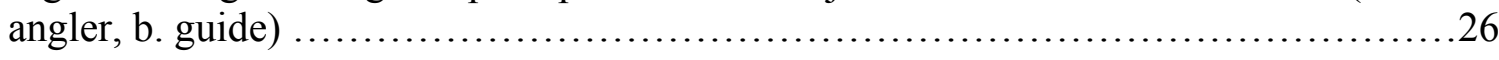

Figure 1A. Example of matrix formatted question for a respondent that reported to have had 15 years of bonefishing experience in South Florida.... 
Figure 2A. Trend of bonefish decline is plotted from the mean scores rated by respondents on the overall quality of the bonefish fishery from 1975 to 2015. The decline trend is separated into 3 major bonefishing regions in South Florida; Biscayne Bay (BB), Florida Bay (FL Bay) and Florida Keys (FL Keys). Respondents were asked to rate their bonefish fishing experience from 1-5 over the time they have been fishing for bonefish in South Florida. Sample size in the figure is based on the respondent sample size however; the trend is based on total response sample size. See methods for further explanation..............................................

Figure 3A. Shifts in fishing effort of 6 regions in South Florida from 1975 to 2015. Fishing effort is calculated from the percentage of fishers that reported to have fished in each of the 6 regions from 1975-2015. Numbers in parenthesis are sample size of each time period......................................................... 45 


\section{ABBREVIATIONS AND ACRONYMS}

Everglades National Park

ENP

Florida Keys National Marine Sanctuary

FKNMS

Local Ecological Knowledge

LEK

National Oceanic and Atmospheric Administration

NOAA

Square Kilometer

Sq. Km.

Traditional Ecological Knowledge

TEK 


\section{BACKGROUND}

Recreational fisheries contribute substantially to local economies, which makes it important to study the effects on the fish that are being caught in order to sustain fish populations and livelihoods. In South Florida and throughout the west-central Atlantic Basin, bonefish Albula vulpes constitute a very important recreational fishery (Larkin et al., 2010) that contributes almost $\$ 1.5$ billion yearly to the Florida economy (VasquezYeomans et al., 2009), supporting livelihoods for professional fishing guides yeararound. Bonefish are a preferred fish species among anglers in the Florida Keys because of their large sizes and their great strength and endurance thereby challenging anglers during capture (Crabtree et al., 1996). Recreational fishing and evidence of bonefish decline have both increased with human population growth and increased fishing pressure (Cooke and Phillip, 2004).

Members of the bonefish fishery community have expressed concern that in the Florida Bay, bonefish populations have greatly declined. Florida Bay is an estuary system that is a part of Everglades National Park (ENP). A variety of anthropogenic changes have been documented and linked to notable changes in the Bay (Figure 1). In the last century, Florida bay has changed from a natural to a highly managed system as a result of the construction of large networks of canals that have diverted freshwater away from the Bay, as well as other notable changes (Stabenau and Kotun, 2012). 
Since the construction of the Flagler railroad and the Tamiami trail in the early 1900s, decreased circulation and freshwater inflow has been observed creating an increase in hyper salinity events (Fourqurean and Robblee, 1999; Light and Dineen, 1994; Porter, 2001; Figure 1). From the mid to late 1900s, the C-111 canal, south Dade conveyance system, droughts, and decreased flow to Taylor Slough caused the Bay to experience a variety of hyper salinity events, increased algal and sea grass productivity, decreased water quality, change in sea grass species composition, algal blooms, and increased turbidity (Fourqurean and Robblee, 1999; Light and Dineen, 1994; Porter, 2001; Figure

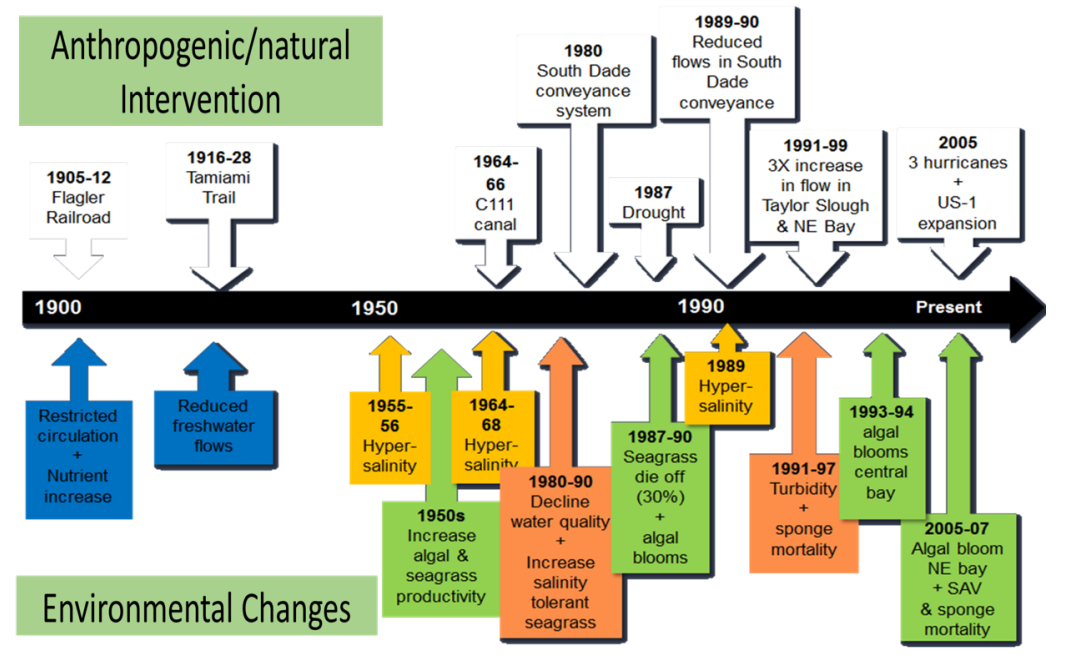

Figure 1. Timeline of anthropogenic and natural alterations that have been linked to changes in the Florida Bay (adapted from various sources; (Fourqurean and Robblee, 1999), (Light and Dineen, 1994), (Porter, 2001))
1). More

recently, with the expansion of US1 and hurricanes

Wilma and Katrina, the Bay experienced more algal blooms and sponge die offs

(Fourqurean and Robblee, 1999; Light and Dineen, 1994; Porter, 2001; Abtew and Iricanin, 2008; Figure 1). These anthropogenic alterations have affected many biotic and abiotic processes which could reduce recruitment for species living in the Bay and the southern Everglades such as pink shrimp, snook, and redfish (McIvor et.al 1994). 
The waters that support of the bonefish fishery in Florida run between Key

Biscayne and Key West. It is uniquely regulated by various agencies both state and

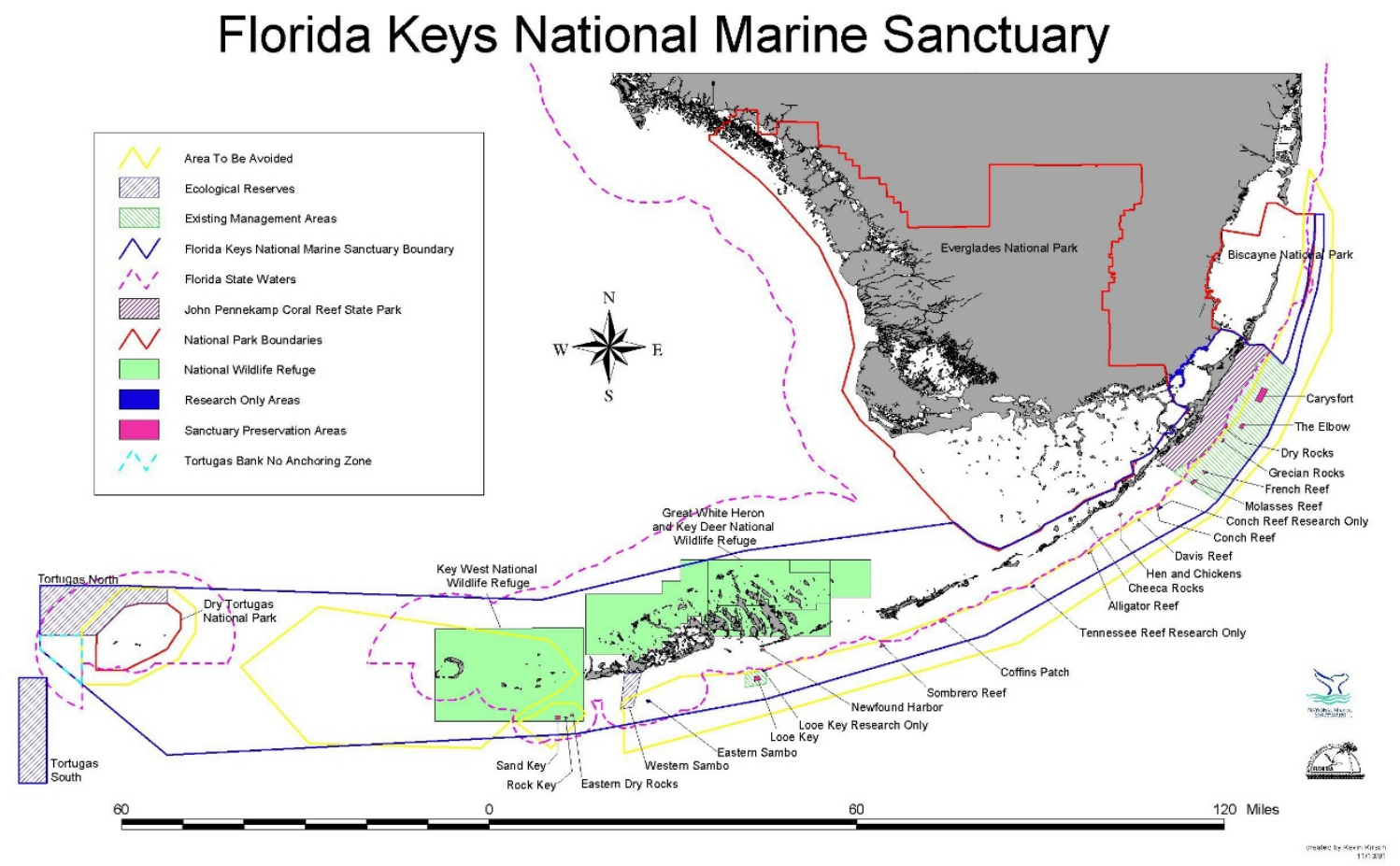

Figure 2. Management and regulation jurisdictions of various agencies in South Florida (NOAA, 2013)

federal with differing regulations and jurisdictions which most notably include: Biscayne, Everglades, and Dry Tortugas national parks, four wildlife refuges, and John Pennekamp Coral Reef State Park (Department of Commerce, Department of Interior, and Florid Department of Environmental Protection) (Ault et. al, 2005). The protected area that covers the largest amount of prime bonefish territory is the Florida Keys National Marine Sanctuary (FKNMS) in South Florida. It was designated in 1990 and is federally run by National Oceanic and Atmospheric Administration's (NOAA) National Marine Sanctuary Program. The purpose of designating this $7,511 \mathrm{sq}$. km. marine protected area (MPA) was to help ensure the protection of various marine habitats including coral reefs, sea 
grass, and mangroves (Suman et al., 1999). The Florida Keys are vulnerable to a variety of adverse changes such as a decrease in water quality, coral bleaching, the die-off of long-spined urchin, decreases in coral cover, declines in reef fish, sea grass die-offs as well as the spread of coral diseases (Keller and Causey, 2005). However, the two major factors that prompted the creation of the FKNMS is its vulnerability to ship grounds and threats to oil drilling (Bohnsack, 1997). In the late 1980s, the threat to drill oil off of the Florida Keys was imminent, but, in 1989, the disastrous Exxon Valdez oil spill took place in Alaska and that same year 3 ships ran into the Florida Reef Tract (Keller and Causey, 2005). As a result of these impacts on the Florida Keys marine ecosystem, Congress was finally prompted to take action and the creation of the FKNMS act was approved in 1990 (Keller and Causey, 2005). When the first management plan was implemented in 1997, it was created with the purpose to ensure resource sustainability by creating a multiple purpose zonation plan (Florida Keys National Marine Sanctuary and Protection Act, 1990, NOAA, 1996, Cooke and Heinen, 2005). The management plan was also implemented keeping in mind prohibition of oil drilling and operating vessels longer than $50 \mathrm{~m}$ (164 ft.) in internationally recognized "Areas to Be Avoided" within and near the boundary of the Sanctuary (Keller and Causey, 2005). With four million tourists that visit the Florida Keys yearly for water related activities, the Florida Keys economy is highly dependent on a healthy ecosystem (U.S. Department of Commerce, 1996). In 1990 half of the Florida Keys population held jobs that were directly or indirectly supported by outdoor recreational activities all of which thrives on a healthy ecosystem (U.S. Department of Commerce, 1996). 
The FKNMS has a unique location as approximately $65 \%$ of the Sanctuary lies within state and federal areas of jurisdiction that are found adjacent to the FKNMS boundary (Figure 2) (Everglades National Park; Keller and Causey, 2005). However, even with the FKNMS and a high variety of other protected areas, bonefish declines are still being observed in South Florida with no definitively known reason for the cause.

Bonefish in South Florida are understudied and what is known about them is mainly limited to research done in the Bahamas (Dallas et al., 2010; Vasquez-Yeomans et al., 2009; Danylchuk et al., 2007a; Danylchuk et al., 2007b; Cooke et al., 2006; Cooke and Phillip, 2004; Crabtree et al., 1996).

Much of this research suggests that a variety of human-induced drivers are thought to be the cause of declines. These include increased fishing pressure as well as catch and release methods causing post release mortality that is associated with handling time and stress. According to Crabtree et al. (1996) fishing mortality as a result of catch and release angling is extremely low; their empirical data show natural mortality and total mortality are similar. Conversely, Cooke and Phillip (2004) suggest post-release mortality of bonefish is relatively high because they expend substantial energy to fight anglers. It is also possible that with high fishing pressure, the same fish are continuously being caught, contributing to high mortality rates. Because of the amount of energy that bonefish expend during the catch-and-release process, red flags have been raised about both the behavior and survival of bonefish after they are released. Both Cooke and Phillip (2010) and Danylchuk et al. (2007) explore the idea of post-release predation causing major bonefish declines. 
Since bonefish expend substantial energy when being angled, they become easy prey for sharks (Cooke and Phillip, 2004). When released in areas with a high abundance of predators, bonefish have an increased risk of mortality. In areas of low shark abundance bonefish are more likely to survive post-release; however, when released in water that had higher shark abundance, $40 \%$ of the fish died within the first hour from shark attacks (Cooke and Phillip, 2004). Many of the fish in this study were observed to remain stationary post release, possibly resulting from the amount of air exposure and equilibrium loss. A follow up study was conducted to look at the effects of recreational angling on bonefish and how equilibrium plays a role in post release mortality. Danylchuk et al. (2007) caught bonefish using two methods, fly fishing and seine netting. They found that bonefish caught by net did not suffer from loss of equilibrium and therefore had a lower rate of mortality by shark predation, while bonefish caught via fly fishing suffered loss of equilibrium therefore increasing their risk of predation after release. It is suggested that the amount of handling time and air exposure after the fish have been caught greatly influence the loss of equilibrium and increase post release mortality. The stress of catch-and-release has been shown to alter physiological processes and impair locomotor skills. Danylchuk et al. (2007) found that bonefish that lost equilibrium spent significant amounts of time swimming in non-directional patterns increasing susceptibility to predators.

It is also suggested that with the amount of stress on fish, predators with sensitive chemoreception (a sensory receptor that can pick up chemical signals in the environment) can more easily pick up on stress hormones being released by angled fish such as cortisol. However, Dallas et al. (2010) tested chemical excretions of angled bonefish and found that stress hormones such as cortisol and lactate were not highly detected. However, bonefish 
excreted both urea and ammonia with high levels of stress. When they exposed lemon sharks to both ammonia and urea they exhibited higher levels of activity, which could mean that excretion that occurs during the catch-and-release process could provide predation cues for certain predators. Catch-and-release angling poses a variety of complications postrelease for Bonefish, which is why it is imperative to better understand the implications and improve on these catch-and-release methods.

Even though Bonefish are being caught and released, they are still suffering massive amounts of energy depletion from being angled that they would otherwise use for predator evasion and other necessities. The amount of energy expended, handling time, and air exposure has been shown to greatly affect the success of these fishes' post-release with loss of equilibrium (Danylchuk et al., 2007) and lack of energy to evade predators, therefore increasing chances of mortality. The literature shows that anglers directly and indirectly influence the mortality of bonefish as a consequence of handling practices during the catch and release process, which poses the question of whether or not current catch-and-release methods are effective means of conservation for maintaining bonefish populations. It is also important to continue understanding of the physiological and behavioral effects of catch-and-release angling on Bonefish, in order to devise strategies to decrease mortality after they are released. Though all of these factors are valid and could be influences in my study, the unique history of ecological changes in the Florida Bay and Florida Keys would suggest that the major factor deals with the changes in the overall ecological health and composition of the South Florida region. In order to better 
understand how Bonefish populations have changed over time I need to know more about the South Florida population.

Unfortunately, since the bonefish fishery is catch and release, there are no quality catch data. To gain an understanding of bonefish decline over space and time, angler knowledge is imperative. The term widely used for this method of acquiring observation data from resource users is called Traditional Ecological Knowledge (TEK) (Berkes, 1993). There is no set definition for TEK since the terms 'traditional' and 'ecological knowledge' are quite vague, however, it refers to a body of knowledge that can be handed down through generations and is normally a characteristic of societies that have a historical continuity in resource use (Berkes, 1993).

While TEK was historically dismissed by scientists and resource managers as it was looked upon as unequal to science, this is now quickly changing as a number of advantages of TEK are being uncovered (Johannes, 1989). Traditional Ecological Knowledge is considered to be valuable for a variety of reasons including; introducing new biological and ecological insights, helping with resource management, protected area and conservation education, informing development planning, and creating more informed environmental assessments (Berkes, 1993). Integrating local knowledge has become increasingly popular as it has been shown to fill in knowledge gaps in scientific data that certain biological assessments cannot consider or are missing because of lack of data (Hall and Close, 2007). Traditional Ecological Knowledge has been used in a variety of studies in order to better understand incomplete scientific data, or help to explain species dynamics especially in fishery settings. Fishermen are a perfect example of a 
community of people that have a continuous history of resource use. Since fisherman spend most of their days out on the water on which they experience a diverse climate, tides, and fish migration patterns, they have a better temporal knowledge than scientific data if such scientific data are not collected over relevant time spans (Close and Hall, 2006). One example of TEK being used in a fishery capacity is after the 1989 Exxon Valdez oil spill in Alaska. One of the species affected by this oil spill was the Pacific herring (Clupea pallasi) which was commercially fished, but their populations declined after the spill (Huntington, 2000). It was uncertain whether their decline was caused by the oil spill or some natural process as a result of too few documented historical data on distribution, spawning, and juvenile habitats of the herring in the region (Huntington, 2000). In the present study 86 fishing communities were interviewed and they were able to get valuable information on what herring populations have been doing for the last 4,000 years. The over exploitation of herring was uncovered to be a major factor in the decline of the fishery. Researchers were also able to pinpoint when certain fishing areas started declining over time (Thorton et. al, 2010). More recently, Beaudreau and Levin (2014) studied the abundance of 22 marine species in Puget Sound, Washington. They used local ecological knowledge (LEK; for the purposes of this paper the term can be used synonymously with TEK) to describe the abundance trends of these 22 marine species, while also assessing how accurate LEK links with the scientific data on the abundance of such species (Beaudreau and Levin, 2014). They interviewed 101 fishermen and asked them to rank the abundances of the marine species qualitatively from 1940 to 2000 (Beaudreau and Levin, 2014). The overall finding of this paper was that, fishermen were able to track decline trends reported by environmental agencies and 
that integrating resource user knowledge and available scientific data can help to fill knowledge gaps about data-poor species (Beaudreau and Levin, 2014). The integration of angler knowledge is very important in data-poor systems and can prove to be very useful when trying to inform on past fish population and distribution patterns which can then help to better inform fish and habitat management for the future.

\section{INTRODUCTION}

Local ecological knowledge (LEK) is an unconventional but useful method of gaining environmental data or information derived from the experience of resource users. Local Ecological Knowledge is especially effective in gaining both temporal and spatial data where there is a general lack of information on a given resource. The use of LEK has been important in a variety of studies in order to inform on the dynamics in data-poor ecological systems (Beaudreau and Whitney, 2016; Daw et al., 2011; Thorton et al., 2010; Lavides et al., 2009; Moller et al., 2004; Olsson and Folke, 2001). The term Locial Ecological Knowledge has progressed from the approach called traditional ecological knowledge (TEK) which refers to acquiring observation data through local knowledge (Berkes, 1993) and for the purposes of this paper will be referred to as LEK. Local Ecological Knowledge has become increasingly popular in vulnerable and rapidly changing ecosystems, not only to document long-term environmental and species change (Beaudreau and Levin, 2014), but also because of its reputation by ecologists that LEK can help to improve research and inform management and environmental assessments (Huntington, 2000). While LEK was historically dismissed by scientists and resource managers as it was looked upon as unequal to science, this is now quickly changing as a 
number of advantages are being uncovered (Johannes, 1989). Local Ecological Knowledge is considered to be valuable for a variety of reasons including: introducing new biological and ecological insights, helping with resource management, protected areas management, conservation education, informing development planning and creating more informed environmental assessments (Berkes, 1993). Integrating local knowledge has become increasingly popular as it has shown to help fill in knowledge gaps in scientific data that certain biological assessments cannot consider (Hall and Close, 2007). LEK has been used in a variety of studies in order to better understand incomplete scientific data or help to explain species dynamics, most commonly in fisheries settings.

Fishermen are a perfect example of a community of people that have a continuous history of resource use. Since fishermen spend most of their days out on the water on which they experience diverse climate, tide, and fish migration patterns, they have a better temporal knowledge than scientific data, when not collected over relevant time spans (Close and Hall, 2006). A variety of studies have shown that the use of LEK can help to inform on fisheries dynamics which include, fish populations, distributions, causes for population changes, and the identification of crucial habitats (Beaudreau and Levin, 2014; Thorton et al., 2010; Huntington, 2000). As highlighted in previous literature, LEK can be a very effective method in understanding the dynamics of fisheries especially when data-poor. Catch and release recreational fisheries such as the bonefish fishery in South Florida have the issue of being data-poor as limited catch data has been collected. It has been recently brought to attention that recreational fishing and evidence of bonefish decline have both increased with human population growth and increased fishing pressure (Cooke and Phillip, 2004). 
The bonefish fishery is a very important component of the South Florida economy, but more specifically to that of the Florida Keys, bringing in about 1.5 billion dollars a year (Vasquez-Yeomans et al., 2009; Ault, 2008) and supporting livelihoods for professional fishing guides, local restaurants, bars and hotels year-around. It is estimated that one single bonefish is worth $\$ 3,500$ per year to the industry. Since bonefish live up to 20 years or more, it was calculated that each bonefish could have a lifetime worth of around $\$ 75,000$. This makes the bonefish fishery 'per fish' one of the most valuable fisheries in the world (Ault, 2008). Bonefish are the preferred fish species among anglers in the Florida Keys because of their large sizes and their great strength and endurance, thereby challenging anglers during capture (Crabtree et al., 1996).

The bonefish fishery is very understudied in South Florida and, having experienced a lot of change over the years, little is also known about the biology, spawning habitats and movement patterns of the species. In recent years, there have been increasing reports of a declining bonefish fishery. Notable bonefish declines were observed by local anglers in the Florida Keys between 2001 and 2012 as well as from 2007 to 2011(Frezza and Clem, 2015). Though times in recent history have been highlighted by anglers as moments of major decline, the question of what the overall decline looked like, when it started, as well as the accuracy of angler perception, still remains unanswered.

To get an understanding of when bonefish started declining and what the decline looked like over time, LEK is imperative. In the case of my study, LEK comes from 
anglers and guides who fish for bonefish in South Florida and have some sort of social or economic investment in the fishery.

In this study, I aim to understand what bonefish decline looked like throughout the South Florida region from 1975 to 2015 by reconstructing a retrospective timeline of the decline utilizing angler and guide knowledge. I wanted to know: 1) what the general perception of bonefish decline has been over time, 2) whether perception changes are based on experience and 3) whether fisher type has an influence on how bonefish decline is perceived. In order to address these questions, I used local ecological knowledge (LEK), which in this context means the knowledge and insight from anglers and guides who have extensive observational experience with bonefish in the South Florida region. Because of limited catch data, I reconstructed a retrospective timeline taken from angler and guide perceptions. I hypothesized that: 1) the overall perception of the bonefish population by anglers and guides will perceive a decline starting from the mid-90s to early 2000s (Frezza and Clem, 2015), 2) with more experienced anglers rating quality more conservatively, over time as anglers with more experience will remember past quality better than anglers with less experience (Ainsworth et.al., 2008), and 3) that guides will rate quality more conservatively over time in comparison to anglers as different stakeholders may have a difference in perception (Suman et. al., 1999). Since guides tend to have more experience, they will also remember past quality better than anglers. 


\section{METHODS}

\subsection{Study site description}

The South Florida bonefish (Albula vulpes) fishery extends from Biscayne Bay to Key West. The waters in this area are unique in that they are managed under both state and federal jurisdictions as a result of the variety of federal protected areas and state parks, all of which are areas that contain bonefish. ENP, an IUCN - World Conservation Union Category 2 protected area (Heinen, 2012), also has the distinction of being a World Heritage Natural Site, a Wetland of International Importance and a United Nations Biosphere Reserve (Heinen, 1995). Florida Bay, with a total area of about 1,593 sq. km. located south of peninsular Florida, is a relatively shallow body of water that consists of sand flats, seagrass beds, mangroves and a high variation of salinity within ENP.

Biscayne National Park, also a Category 2 protected area comprised of over $95 \%$ shallow marine habitats is located on the Atlantic side of South Florida from the southern end of Key Biscayne to the northern end of Key Largo (Figure 2).

More recently, compared to the two parks, the Florida Keys National Marine Sanctuary (FKNMS) was established by Congress in 1990. It is a $7,911 \mathrm{sq}$. km. marine protected area that includes areas along the expanse of the Keys from Key Largo in the northeast to the Dry Tortugas in the west. FKNMS is managed by the National Oceanic and Atmospheric Administration's National Marine Sanctuary program. It is zoned into various classifications that include some areas with very strict protection (e.g. no fishing in many cases and no entry in some cases; Cook and Heinen 2005). Portions of the reef ecosystem from Key Biscayne and along the Keys are also managed by various state and federal agencies with differing jurisdictions and some different fishing regulations (Ault 
et al., 2005). The area from Key Biscayne to Key West is particularly vulnerable to adverse changes as a result of increasing populations, coastal development and fishing exploitation (Ault et al., 2005). The economic mainstay of the region is tourism and sport fisheries along with snorkeling and diving; these are the most important activities of tourists in terms of revenue generation.

\subsection{Interview approach and survey design}

I designed my survey and collected angler and guide perception data through an online survey using Qualtrics (www.cast.fiu.edu/projectbaybones.com). My goal was to reach out to as many anglers and guides as possible with varying experience levels. Most of my questions were multiple choice and formatted as a 5-point Likert scale question (Heinen and Shrivastava, 2009) while other questions were in short answer format. The online survey method was chosen over other methods because I needed to reach out to high numbers of people throughout the United States. The survey was open for six months from August, 2015 to January, 2016, with an overall completion rate of 48\% yielding a total of 278 respondents. The method I used to get my sample of 278 respondents is known as the cluster sampling method, which is most effective when trying to reach out to scattered groups of people (Bernard, 2006). In my study, there are scattered populations of anglers and guides who fish for bonefish in South Florida, throughout the United States. The cluster sampling method refers to sampling within all of those groups. Since my survey was online, I was able to sample a diverse group of fishers by making the link available to 2,500 Bonefish and Tarpon Trust members, two Florida Keys guide associations as well as regional and national advertising in the Guy Harvey magazine, Florida Sportsman, the Miami Herald, the Fort Lauderdale Sun 
Sentinel and Florida International University news. Locally, I was also able to set up displays advertising the survey in major fly shops in Miami and the Florida Keys. As a result of my diverse forms of advertising, I was able reach a very large and diverse population of bonefish fishers (Table 1).

Table 1. Demographics of total respondents in percentages

\begin{tabular}{llc}
\hline \hline Demographic & & \\
Parameter & Level & $\%$ \\
\hline Gender & Female & $5 \%$ \\
& Male & $95 \%$ \\
\hline Age & Under 21 & $1 \%$ \\
& $21-34$ & $12 \%$ \\
& $35-44$ & $15 \%$ \\
& $45-54$ & $20 \%$ \\
& $55-65$ & $23 \%$ \\
& over 65 & $29 \%$ \\
\hline Experience & $5 y$ yrs & $13 \%$ \\
& $10 y r s$ & $12 \%$ \\
& $15 y r s$ & $13 \%$ \\
& $20 y r s$ & $19 \%$ \\
& $30 y r s$ & $20 \%$ \\
& $40 y r s$ & $11 \%$ \\
Angler type & $>40 y r s$ & $13 \%$ \\
\hline Organization & Guide & $19 \%$ \\
affiliation & Angler & $81 \%$ \\
\hline & Non-affiliated & $36 \%$ \\
& Affiliated & $64 \%$ \\
& Bonefish and Tarpon Trust & $48 \%$ \\
& Other affiliations & $52 \%$ \\
\hline
\end{tabular}

I wanted to extract information on when and where anglers or guides fished and what they thought of the fishery's overall quality. I then decided to break up quality into size and number retrospectively as well. In order to achieve this, I formatted this question as a matrix with time in years $(2015,2010,2005,2000,1995,1985,1975)$ along the top and regions that I delineated on the basis of the Everglades National Park delineation and the Florida Keys general areas (Biscayne Bay, NW Florida Bay, NE Florida Bay, SW Florida Bay, SE Florida Bay, Upper Keys, Middle Keys, Lower Keys; Figure 1A). I designed my survey to maximize the amount of data I could collect since I could not conduct the study throughout time and data had to be collected retrospectively. When 
collecting data retrospectively it can be difficult to attain larger sample sizes because as you go back in time you lose numbers of respondents. As a result of this format, I was able to increase the amount of data I could collect by expanding the amount to times each angler could answer, so instead of one response per respondent, each respondent could answer multiple times within a given matrix because they could fish in multiple regions and years.

Respondents were asked to evaluate the quality of their fishing and specific component of fishing quality (number of opportunities or shots of catching bonefish and bonefish fish size at present, 5, 10, 15, 20,30 and 40 years ago corresponding to seven time steps: 2015, 2010, 2005, 2000, 1995, 1985 and 1975). Respondents were also asked to evaluate these three parameters spatially across regions for the areas they fished (Florida Bay vs. Biscayne Bay vs. Florida Keys) over the subset of time steps that they fished, such that each respondent filled a custom made matrix of time fished across regions fished based on the length of time they reported to fished for bonefish in South Florida (Figure 1A). Spatial analyses however are beyond the scope of this paper and are reported elsewhere, thus I focus my analysis to all regions combined.

For overall fishing quality, anglers were asked to rate bonefishing on a scale of 15 (1-very poor, 2- poor, 3-fair, 4-good, 5-very good). For size and quantity of bonefish I provided anglers with reference points by which to score these components of fishing quality. By using quantitative reference points, my study was able to overcome the high variation in perceptions, which was a method adapted from the fuzzy logic approach (Zadeh, 1965). Since the creation of fuzzy logic by Zadeh (1965), it has been applied to 
marine management (Teh and Teh, 2011), fisheries conservation (Ainsworth et al., 2008; Ramos et al., 2015; Grant and Berkes, 2007), as well as other areas of ecology and disciplines when relying on qualitative data that needs to be quantified (Prato, 2011). As Zadeh (1988) explains, unlike most logical systems, the purpose of fuzzy logic is to model the imprecise ways of reasoning that are common in a human's ability to make rational judgments in the presence of uncertainty. As a result, the ability to infer an answer is based on an individual's knowledge base that is imprecise and imperfect (Zadeh, 1988). By using fuzzy logic, data can be processed in a way that will allow for a degree of true statements instead of just true or false (Prato, 2011) because unlike scientific data, human knowledge is qualitative and consist of fuzzy sets (continuous grades of membership, not just true or false) (Grant and Berkes, 2007; Zadeh, 1965). Since LEK is qualitative, fuzzy logic can help to frame qualitative variables into a format that can be more easily quantified (Teh and Teh, 2011). By assigning ranges that were relatable to fishers, we could assign those ranges to a 1-5 scale that would allow for a smoother transition for quantitative analysis. The fuzzy logic approach stems from the idea that vagueness and shifting baselines are inherent in LEK, so fuzzy logic is able to present a method for standardizing uncertain and or contradictory information (Ainsworth et al., 2008). Using the fuzzy logic approach in the context of anglers and their varying years of experience offers a solution to the issue of differing baselines and reference points.

For bonefish size, fishers were asked to rate each dimension from $1-5$ as $1=<2 \mathrm{lbs}$, $2=2 \mathrm{lbs}-5 \mathrm{lbs}, 3=6 \mathrm{lbs}-8 \mathrm{lbs}, 4=8 \mathrm{lbs}-10 \mathrm{lbs}, 5=>10 \mathrm{lbs}$. For bonefish number, fishers were 
asked to score the number of shots or attempts at catching a bonefish $(1=0$ shots, $2=1$ 3 shots, $3=4-10$ shots, $4=>10$ shots, $5=$ unlimited shots). Shots refers to how many times a fisher had an opportunity to cast at a bonefish. Bonefishing is done by sight fishing and therefore you must actually see them before you can cast for them (Fernandez and Adams, 2004). I chose to define the number of bonefish by 'shot' so I could get a better estimate of actual numbers versus bonefish caught, as that would be affected by fisher experience. The rating scale used was a standard 5-point Likert scale, and these reference points were developed in consultation with experienced anglers and guides on what constitutes a good vs. bad bonefishing day. The interview approach followed Beaudreau and Levin (2014) where they asked fishermen to provide seven qualitative rankings to 22 different Puget Sound marine species through time. I assigned each number on the 1-5 Likert scale a range or category so that each angler and guide would have a standardized baseline or reference, which is an idea I incorporated from the fuzzy logic approach from Ainsworth et al. (2008). Though the spatial representation of bonefish decline is an important factor to my data collection, it is not in the scope of this particular paper. However, it will be fully explored in a later publication.

In addition to the semi-structured interviews, I also conducted key informant interviews to gain a deeper knowledge of the fishery and get a retrospective idea of bonefish populations in South Florida. Key informant interviews are a series of open ended questions that can spur meaningful discussion on a specific topic. I directed these interviews towards the older members of the fishery community that have a long history with bonefishing in South Florida to get quality decadal and spatial data on where 
bonefish were fished. I interviewed a total of 20 guides and anglers. Each interview was recorded and lasted anywhere from 30 minutes to 2 hours. Every interview was then transcribed and I was able to extract coordinates of where bonefish populations have shifted over the last 40 years and map them on ArcGIS 10.1. Using key informant interviews, though a more qualitative method of data collection, can produce important quantifiable results and has been used in many contexts throughout the socio-ecological literature (Garcia-Lozano and Heinen, 2015; Dongol and Heinen, 2012; Heinen and Shrestha-Acharya, 2011; Ter-Ghazaryan and Heinen, 2006; Olsson and Folke, 2001).

\subsection{Statistical Methods}

In order to quantify the temporal trends from the matrix data, I combined all regions and averaged the 1-5 scores across all seven time steps for all respondents that scored in that time step.

Two-way ANOVAs were run in the basic R statistical package in order to test for variation in 1) bonefishing quality, 2) bonefish number, bonefish size and 3) as a function of time steps and two other relevant factors. My two models were:

1. Time + Angler Experience + Time* Angler Experience

2. Time + Fisher Type + Time* Fisher Type (Angler vs. guide)

I ran post-hoc Tukey tests to examine variation across individual time steps in order to see where decline was perceived to start. 


\section{RESULTS}

\subsection{Perceptions of bonefish decline}

Respondents perceived an overall bonefish decline over the last 40 years. The declining trend was consistently perceived for overall bonefishing quality, bonefish number and bonefish size (Tables 2-3). Respondents perceived a 47\% decrease in overall quality, scoring on average 4.3 out of 5 in 1975 to a score of 2.3 in 2015. Over time, however, bonefishing quality did not decrease at a steady rate (Figure 3). From 1975 to 2000 there was a perception of no change $(\mathrm{p}=0.985)$, followed by a perceived difference from 2000 to $2005(\mathrm{p}<0.05)$. The decline seemed to accelerate between 2005 to 2010 $(\mathrm{p}=0.000)$, and was followed by no difference between $2010-2015(\mathrm{p}=0.798)$. This is also corroborated through the key informant interviews as over $50 \%$ of the key informants interviewed stated that they started noticing major bonefish decline from the early 1990s to the early 2000s (Table1A).

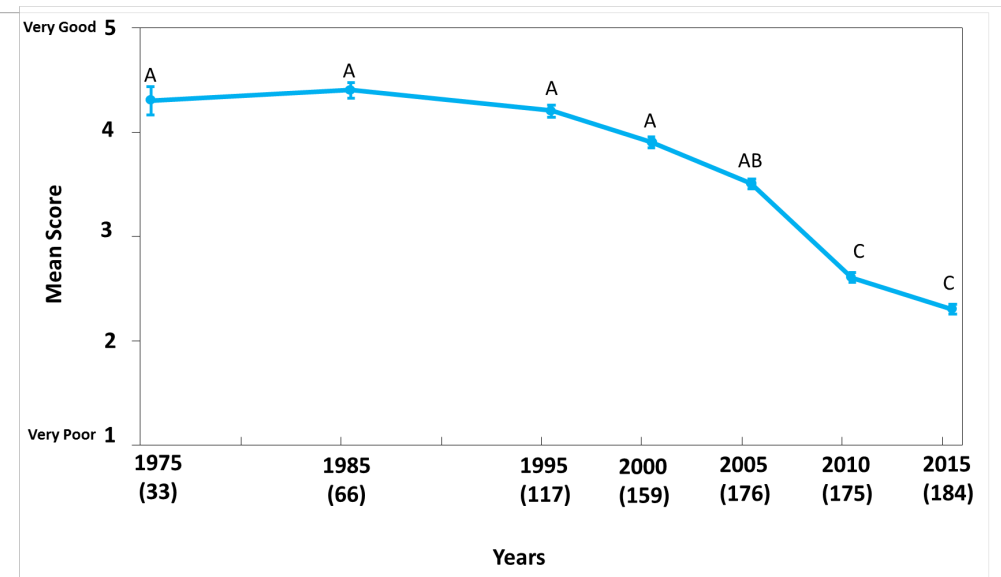

Figure 3. Trend of bonefish decline is plotted from the mean scores rated by respondents on the overall quality of the bonefish fishery from 1975 to 2015. Respondents were asked to rate their bonefish fishing experience from 1 to 5 over the time they have been fishing for bonefish in South Florida. Error bars are based on standard error and letters above are differences based on post hoc Tukey tests. Sample size in the figure is based on the respondent sample size however, the trend is based on total response sample size. See methods for further explanation. 
When I decomposed quality into two separate categories, number and size, the pattern of decline was different (Figure 4). Over all time steps, the decline in number was perceived to be higher than the decline in size. Respondents perceived about a $40 \%$ decrease in bonefish number scoring on average a 4.0 out of 5 in 1975 to 2.4 in 2015 , whereas size was scored 3.7 to 2.5 (32\% decrease in size) for the same time period (Table 2). Further, the decline in number starts earlier than the decline in size (1985 for number vs. 2005 for size). Similar to the overall pattern in bonefishing quality, bonefish size was perceived to have not changed from 1975 to 2000 ( $p>0.65)$. Also, 2005 looks to be a transitional year for size decline as it was the same and different to post and previous years (Figure 4). However, respondents also perceived a difference from 2005 to 2010 $(\mathrm{p}<0.001)$.

Respondents perceived a decline in number differently from size and overall quality, but was also found to be significant ( $\mathrm{p}<0.001$, Table 1). From 1975-1995 respondents perceived that there was no change in number of bonefish $(p>0.981)$. Number and size received the same rating in 2000, at which point respondents started to observe a noticeable decline in size that was apparent until 2015. However, for number, 1995-2005 shows transition from no change to decline as the year 2000 was both the same and different as 1995 and 2005 (Figure 4). The post-hoc Tukey test also showed that respondents again, perceived a difference between 2005 and $2010(p<0.001)$ 

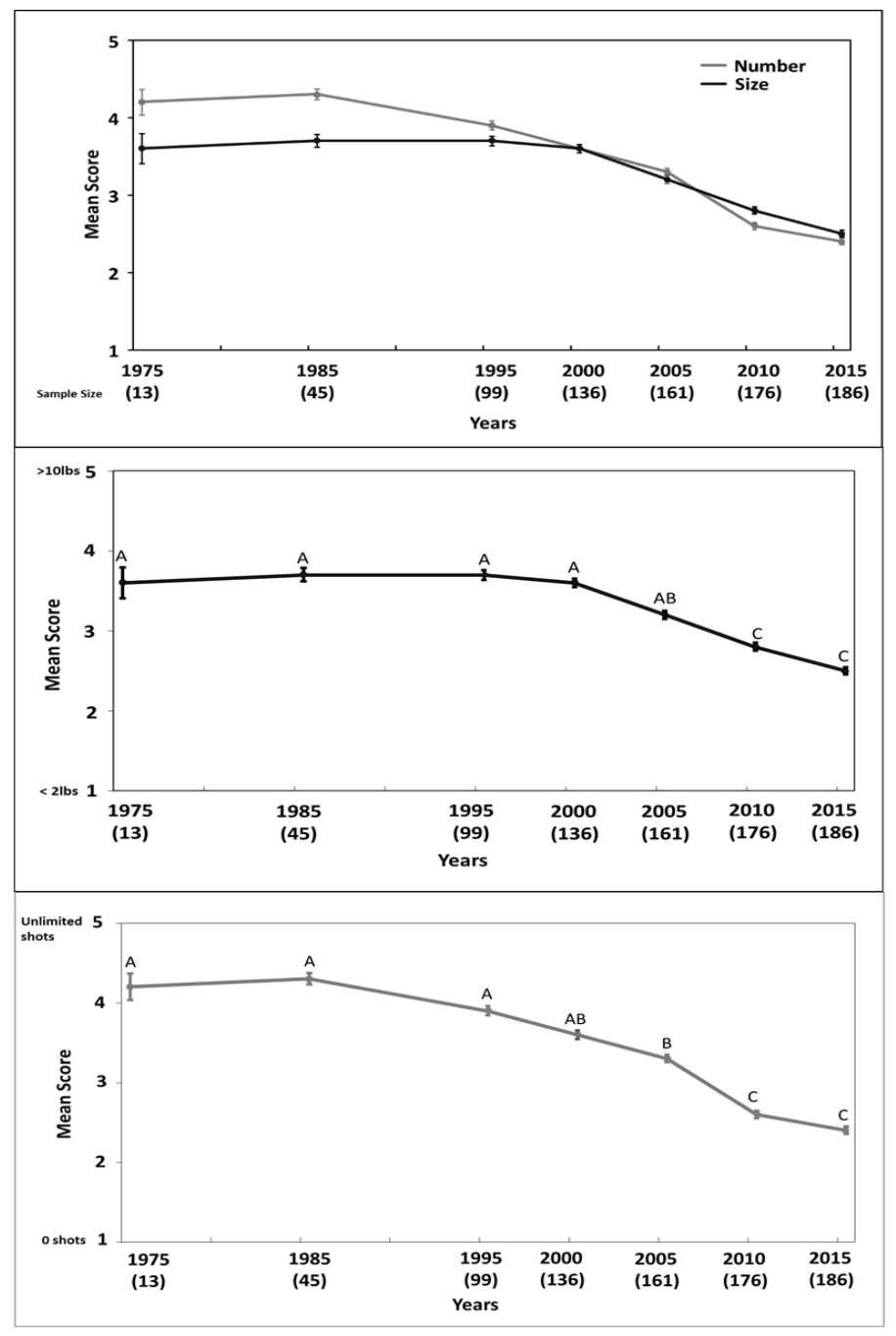

Figure 4. Overall bonefishing quality can be divided into two factors, number of bonefish caught and size of bonefish caught. When quality is divided into these two factors, the decline trend looks different. Respondents were asked to rate from 1 to 5 how number and size of bonefish changed from when they started fishing for bonefish in South Florida. The middle and bottom figure are both size and number trends separated. Letters are based on post-hoc Tukey tests and error bars are based on standard error. Sample size in the figure is based on each respondent; however, the trend is based on total response sample size. See methods for further explanation.

\subsection{Perceptions of bonefish decline related to fisher experience}

With varying years of angling experience, I found that there was a difference in experience among anglers who scored their bonefishing experience over time $(p<0.05$, Table 2), however, this was only significant when respondents were asked about the overall quality of the fishery. There was no significant difference in angler experience for 
size or number of bonefish $(\mathrm{P}>0.05$, Table 2$)$. For the variation in angler experience, the most experienced angler group (40 years) scored on average lower than all other experience level, while in 2005 the 10-year angler group scored the highest, showing evidence of shifting baseline (Figure 5a). I tested the interaction between angler experience and perception and found no significance in any of the three indicators $(\mathrm{P}>0.05$, Table 2). However, there is a trending significance for the interaction between angler experience and time for the size parameter $(\mathrm{P}=0.063$, Table 2$)$ In this case, the 40year angler group scored on average the higher than the 20-year angler group from 19952005 until they cross and the 20-year angler group scores lower on average than the 40year angler group from 2010-2015 (Figure 5b.).

Table 2. Summary of statistical output from an ANOVA on bonefish fishery quality scored by bonefish anglers $(\mathrm{N}=278)$ from 1975 to 2015 . Fishery quality is put into 3 different categories (overall quality, size, and number). Variables tested were: time, angling experience, and the interaction between time and angling experience. $(* * * \mathrm{P}<0.001, * * \mathrm{P}<0.005, * \mathrm{P}<0.05)$

\begin{tabular}{lccc}
\hline \hline Variables & $\mathrm{F}$ & $\mathrm{df}$ & $\mathrm{P}$ \\
\hline Overall Quality & & & \\
Time & 68.5 & 6 & $<2 \mathrm{e}-16^{* * *}$ \\
Angler Experience & 3.5 & 2 & $0.0283^{*}$ \\
Angler Experience ${ }^{*}$ Time & 0.5 & 12 & 0.862 \\
\hline Size & & & \\
Time & 30.7 & 6 & $<2 \mathrm{e}-16^{* * *}$ \\
Angler Experience & 1.2 & 2 & 0.287 \\
Angler Experience ${ }^{*}$ Time & 1.6 & 12 & 0.063 \\
\hline Number & & & \\
Time & 41.7 & 6 & $<2 \mathrm{e}-16^{* * *}$ \\
Angler Experience & 0.6 & 2 & 0.502 \\
Angler Experience ${ }^{*}$ Time & 0.1 & 12 & 0.999 \\
\hline
\end{tabular}



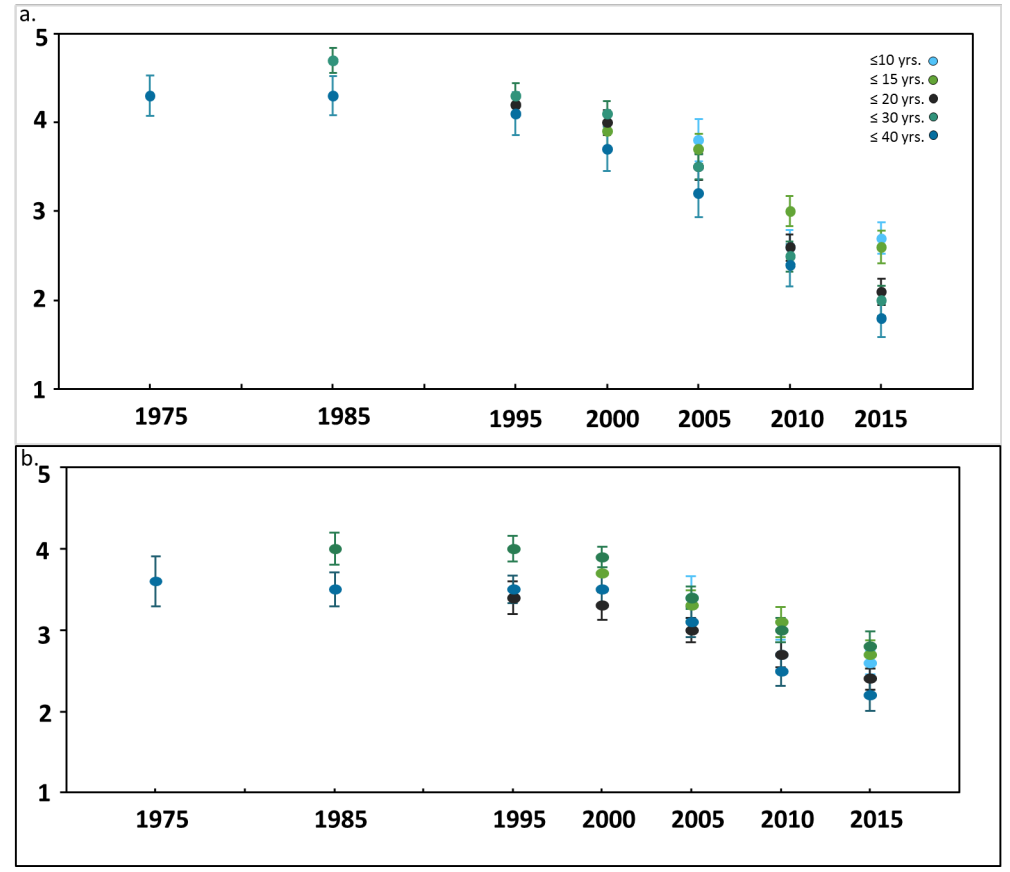

Figure 5. Angler experience plotted by time (a. overall quality parameter, b. size parameter) Error bars are based on standard error.

\subsection{Angler versus guide perceptions}

I found differences in perception of all three parameters across anglers vs guides, but fisher type had no effect on the perception over time (Table 3). Guides scored quality of bonefishing, size and number to be higher quality relative to anglers (Figure 6).

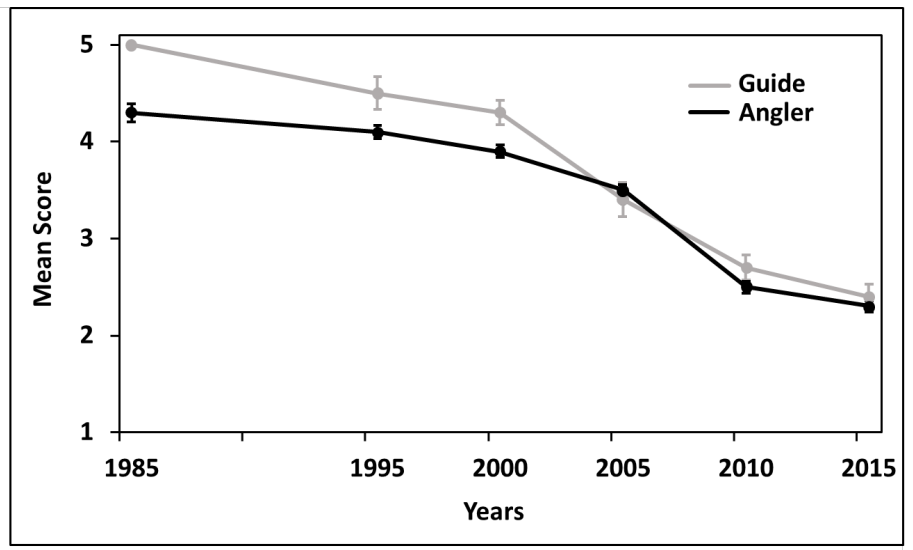

Figure 6. Comparison of perceived bonefish decline trend between fisher type (guides and anglers). 
After asking respondents about their perceptions on bonefish decline, I also asked them about what they thought the major causes of bonefish decline were. Since anglers and guides may have different perceptions, I looked at the differences between their reasons of decline. I found that both anglers and guides said that pressure as a result of over fishing, poor handling practices, increased boat traffic and water quality were the top reasons for why bonefish were declining (Figure 7).

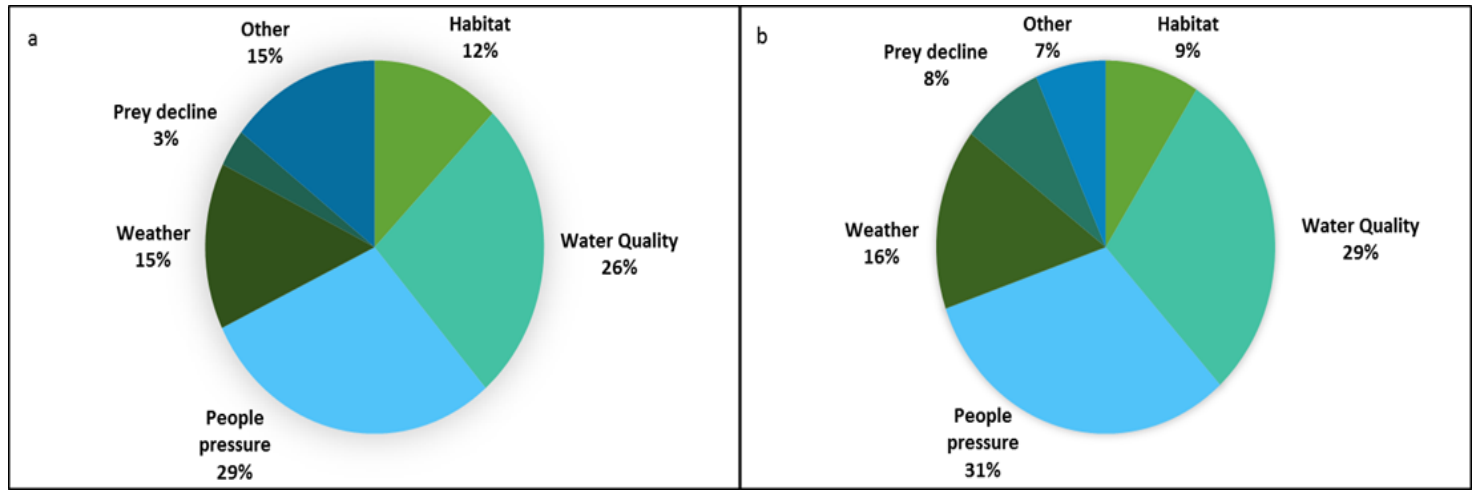

Figure 7. Angler and guide perceptions of the major causes for bonefish decline (a. angler, b. guide).

Table 3. Summary of statistical output from an ANOVA on bonefish fishery quality scored by bonefish anglers $(\mathrm{N}=278)$ from 1975 to 2015 . Fishery quality is put into 3 different categories (overall quality, size, and number). Variables tested were: time, fisher type, and the interaction between time and fisher type. $(* * * \mathrm{P}<0.001, * * \mathrm{P}<0.005$, $* \mathrm{P}<0.05$ )

\begin{tabular}{lccc}
\hline \hline Variables & $\mathrm{F}$ & $\mathrm{df}$ & $\mathrm{P}$ \\
\hline Overall Quality & & & \\
Time & 68.9 & 6 & $<2 \mathrm{e}-16^{* * *}$ \\
Fisher Type & 8.5 & 1 & $0.003^{* *}$ \\
Fisher Type * Time & 0.4 & 5 & 0.803 \\
\hline Size & & & \\
Time & 59.2 & 6 & $<2 \mathrm{e}-16^{* * *}$ \\
Fisher Type & 6.3 & 1 & $0.012^{*}$ \\
Fisher Type ${ }^{*}$ Time & 0.5 & 5 & 0.736 \\
\hline Number & & & \\
Time & 64.5 & 6 & $<2 \mathrm{e}-16^{* * *}$ \\
Fisher Type & 8 & 1 & $0.004^{* *}$ \\
Fisher Type * Time & 0.4 & 5 & 0.805 \\
\hline
\end{tabular}




\section{DISCUSSION}

Since bonefish are very understudied in South Florida, little is known about them, making it difficult to come up with the best management practices for their populations. I improved on the bonefish knowledge base by being able to inform on what has been happening with bonefish populations over the last 40 years with the utilization LEK. In order to later integrate timelines of environmental change in South Florida, the main goal of my paper was to quantify qualitative data. I was able reconstruct a retrospective timeline of bonefish decline to gain a better overall understanding of bonefish populations. My study adds to the increasing body of literature on the integration of LEK to inform biological assessments (Beaudreau and Levin, 2014, Thorton et al., 2010, Daw et al., 2011). Furthermore, with the implantation of the fuzzy logic approach (Ainsworth et al., 2008; Zadeh, 1965) I was also able to minimize the amount of bias when using survey data.

The first question I was interested in answering was: what is the general perception of bonefish populations over time? I expected that the general perception on the bonefish decline would start in the mid-90s to early 2000s. Perceived trends by bonefish anglers suggest that bonefish populations have declined since 1975 (Figure 3). I found that bonefish decline is consistent across all three quality parameters ( $<<0.001)$, Table 2$)$ as respondents perceive the bonefish population to have been declining since 1975 (Figure 3). When I decomposed quality into two categories: size and number, it was interesting to see that fishers perceived both of these aspects of quality to have declined differently (Figure 4). Fishers did not perceive a decline in size until about 2000 while number was perceived to have started to decline in 1985 (Figure 4). In the case of overall quality and 
size parameters, fishers perceived the decline to start between 2000 and $2005(\mathrm{p}<0.05)$, while for the number parameter, fishers perceived the start of the decline to be between 1995 and $2005(\mathrm{p}<0.05)$ with 2000 being a transition year (Figure 4).

With perceived decline starting anywhere between 1995-2005 (based on all three parameters), a variety ecological and anthropogenic changes could have been a cause. From the mid to late 1900s, the C-111 canal, south Dade conveyance system, droughts, and increased water flow to Taylor Slough caused the Florida bay to experience a variety of hyper salinity events, increased algal and sea grass productivity, decreased water quality, change in sea grass species composition, algal blooms, and increased turbidity (Figure 1). More recently, with the expansion of US-1 and the three recent hurricanes, the Florida bay has experienced more algal blooms and sponge die offs (Figure 1). These anthropogenic alterations have affected many biotic and abiotic processes contributing to a reduced recruitment for species living in the Bay and the southern Everglades such as pink shrimp, snook, and redfish (McIvor et.al 1994). Bonefish populations could have also been affected by any number of these ecological changes as well. A very consistent point of decline in all three parameters was from 2005-2010 which could be indicative of a12-day cold event in 2010 that resulted in high volumes of fish mortalities (Colella et al., 2011). With fishers picking up on an overall decline of both size and number, this could be symptomatic of an overharvested fishery or reduced growth rates (Haedric and Barnes, 1997). Though a decrease in size could be interpreted as good recruitment (Haedric and Barnes, 1997), this is unlikely since the number of bonefish have also been perceived to have declined. This is an interesting deduction as in theory, non-consumptive fisheries should not be able to 
collapse since there is no direct harvesting. Therefore, one factor that should be explored is the role of human predator behavior in the bonefish fishery because with the addition of possible deposensatory fish mortality, theoretically this would lead to a predator-prey system vulnerable to instability and collapse (Post et. al., 2002). Though the bonefish fishery is catch and release and non-harvest, there is still evidence of notable post release mortality (Cooke and Phillip, 2010; Dallas et al., 2010; Danylchuk et al., 2007; Cooke and Phillip, 2004). Possibly a combination of fishing pressure and rapid environmental change is driving the bonefish decline even in a non-consumptive fishery such as this.

Guides I interviewed have described clear observations of major declines in bonefish throughout South Florida. For example, one of my key informants stated:

"There are no bonefish by historical standards. If you go bonefishing for a full day you would go to 8 or 10 spots. You may find bonefish at 3 or 5 of them. Sometimes you'd find fish at 7 of them. Today you go to 10 spots, you may find them at 1 or 2. That's the difference. Let's say you have 300 fish and there on a flat out here and they come up and feed and you have a couple good hours of fishing. Then the tide changes, the fish go away and you go look for another spot and you don't find anymore that day. You go back the next day and those fish have moved a mile. So you don't see them. Whereas historically there would be 300 fish on that flat, another 300 over here, some more a mile away, so with frequency you would hit the right spots. Now, you can't count on that. There are so few." 
To build off of this apparent declining trend, I was also able to quantify decline by three regions throughout South Florida (Biscayne Bay, Florida Bay, Florida Keys) and found that though each region was still perceived to have declined, they were perceived to have declined differently (Figure 2A). I also noticed that as regions experience decline, fishing effort in each region also changed over time (Figure 3A). These major connections will be made more apparent in a future publication.

One common criticism when relying on perception and human memories to recount the past is that shifting baseline syndrome should be accounted for. Shifting baseline syndrome is the change in perception of a biological system as a result of the lack of experience with past conditions (Pauly, 1995; Papworth et. al, 2009). The potential risk of capturing a shifting baseline in data is that it can lead to highly variable resource assessments. Daw (2010) points out that this is not a question of the accuracy of fishers' perceptions, but how to handle information that has a wide range of biases so as not to exaggerate or mask trends. However, in a data-poor system where I am not able to go back in time to sample, I must rely on the knowledge of the resource users, which in this study are anglers and guides. This framework allows for the integration of human interactions with environment and ecology to create more effective management strategies to benefit both social and biological systems (Huntington, 1998). Those who I surveyed included anglers of varying years of experience ranging from 5 or less to 40 or more years leaving room for the possibility of shifting baseline. I was able to account for shifting baseline syndrome by making sure I had a large sample size, and by integrating the fuzzy logic approach in order to standardize inconsistent responses (Zadeh, 1965). 
Understanding this risk of capturing shifting baselines in my data set, my second question was whether perception changes based on experience. If so, my data would have evidence of a shifting baseline. I expected that with varying years of experience, the more years of experience an angler had, the more conservatively they would score their fishing quality over time. Though there is evidence of perceived decline over all three indicators, angler experience was only different in the overall quality parameter $(\mathrm{p}=0.0282$, Table 2 , Figure 5a). When I tested the interaction between angler experience and how they scored over time, there was no significance in all three indicators (Table 3), though this interaction was trending in reference to size $(\mathrm{p}=0.06$, figure $5 \mathrm{~b})$. This could suggest that we have a slight effect of the variation of angler experience and possibly slight evidence for shifting baseline. Unlike like previous studies (Beaudreau and Levin 2014, Ainsworth et al. 2008, and Saenz-Arroyo et al. 2005) I cannot completely support or reject my hypothesis for shifting baseline, as I have conflicting data showing both evidence and no evidence for shifting baseline. I can support that for overall quality, the most experienced group ( 40 years) did consistently score lower on average over time, which would lend support to my hypothesis that anglers with more experience would score more conservatively. (Table 2, Figure 5). However, for all other parameters there was no evidence of this difference.

Given that I found a difference in angler experience among years for overall quality, this could suggest that since I used subjective ranges for the scoring of this parameter, shifting baseline could still occur as memories are also subjective. However, with the use of objective ranges for the other two parameters I was able to minimize the presence of shifting baseline (see methods). I standardized my 5-point Likert scale by 
attaching ranges so that every angler independent of their experience would have the same frame of reference when scoring fishery quality in terms of at least two parameters (size and number). By applying this approach to standardize my responses perhaps I was able to minimize the presence of shifting baseline biases. This is supported with the size and number parameters showing no difference of years of experience influencing the overall scoring of size and number (Table 3). A more social reason for why I may not see evidence of shifting baseline is because of the communicative culture of the bonefishing community in South Florida. Grant and Berkes (2007) found that fishers tend to learn and share knowledge through apprenticeship, mentorship, and/or information sharing where which their knowledge base is continually updated during small informal social gatherings where they discuss experiences and strategies. The time spent interviewing bonefish anglers and guides, I found that there is a prominent culture in which anglers and guides that have more years of experience pass down their knowledge on historical bonefish and environmental changes. As a result of continuous knowledge transfer between generations, it has possibly homogenized perception so that evidence of shifting baselines is not apparent.

Knowing that different stakeholders could harbor different perceptions (Suman et al., 1999), my last question focused on the disparity between anglers and guides because they may hold different stakes in the bonefish fishery. I wanted to know if experience type (angler or guide) would show a difference in how bonefish decline is perceived. I expected that guides would score more conservatively on average in comparison to anglers. Guides tend to have longer and more continuous experience in the fishery, while also look to the fishery for recreation as well as a livelihood. Anglers may also have long 
term experience in the fishery but is more likely to not be not continuous (visit once or twice a year to fish) and they look to the fishery purely for recreation. According to my survey data, anglers scored lower on average from 1985 to 2015 compared to guides with exception 2005 were the score was almost the same (Figure 6). Though I found that there was a significant difference between anglers and guides at each time step (Table 3), there was no significance between fisher type and their scoring overtime (Table 3). I reject my hypothesis that fisher type has an influence on the way they scored and that guides would rate quality more conservatively over time. Though anglers and guides may have different investments in the fishery, there are a lot more declared anglers than guides (Table 1). Since there is such a large difference in the number of anglers and guides in my data set, any real significance may be masked by the large difference in sample size. As mentioned previously, the bonefish angling culture is centered around the transfer of knowledge from generation to generation, which may be true in this scenario causing the responses to be similar over time. In the survey, I also asked respondents what they thought the major reasons for bonefish decline were. When I separated the responses between anglers and guides I found no difference in response, both anglers and guides said the major reasons for bonefish decline were 1) people pressure and 2) water quality. This finding is interesting because it also lends support to the idea that fishers accumulate their experiences and observations among each other (Grand and Berkes, 2007). It is also interesting that in both cases people pressure is the highest stated reason for decline which consequently supports findings on the significance of post-release mortality brought on by increased fishing pressure (Cooke and Phillip, 2010; Dallas et al., 2010; Danylchuk et al., 2007; Cooke and Phillip, 2004). 


\section{CONCLUSION}

The phenomenon of shifting baseline syndrome is a very common occurrence when utilizing LEK and relying on the memories of people with various lengths of experience. Though the risk of shifting baselines can cause highly variable biological assessments, relying on LEK is still vital when trying to assess the vulnerabilities of data-poor species, such as bonefish. Continued research must be done in order to create a more seamless way of quantifying traditionally qualitative information in a way that does not present troublesome biases. Perhaps the continued integration of citizen science programs such as ‘Citizen Angler Science Team' (CAST; Lee, 2015), which was started at Florida International University to integrate LEK with current and ongoing scientific research, would lessen the disparity between both approaches. By using approaches such as fuzzy logic, biases that are inherent when using LEK can be minimized, as supported by this paper. With bonefish declining, there is a serious negative implication for guides that make a living off of taking anglers bonefishing. One guide stated:

"It's all down to the clients, bonefishing used to be about $80 \%$ of my business and then I did a little tarpon and a little bit of permit fishing, but once I lost bonefish I lost $80 \%$ of my business."

Overall the bonefishing community in South Florida cares very deeply about the bonefish resource not only as a means of livelihood sustainability, but for the pure intrinsic and sentimental value of the fishery. By conducting multiple key informant interviews, I found that the most established anglers and guides are a very environmentally conscience and self-aware group that pass down this mentality to the rest 
of the South Florida angling community. Much of the bonefish angler and guide community share the following sentiment:

"I would do things differently now knowing what has happened with the bonefish population. I would change things around 1) not bringing bonefish back to the dock, and 2) be a little bit more gentle with my releases and not fish certain areas over and over again and over pressure these fish. I should have been doing this research over 10 years ago, not now, and I wish that I had that chance with bonefish again and maybe I will one day with your help and help of others. I wish I knew, I wish I knew then what was going on so it would be a whole different ball game and I might have been able to save the whole population a little quicker." It is fortunate that the South Florida region does not purely rest on the economic contribution of bonefish, but also is known for the variety of successful fisheries in the area so that even though bonefish are declining, there are other fisheries that draw in tourists and anglers from all over the nation:

"We are still the fishing capital of the world for one reason only. If you want to catch bonefish you go to the Bahamas, if you want to catch a redfish you go to Louisiana, but we are the only place in the world where you can catch maybe even in one flat a permit bonefish, tarpon, snook and reds, go offshore and catch wahoo, sailfish, tuna, dolphin, and kingfish. All that and then in patches go lobstering get hogfish, grouper and go in the gulf and catch cobia, and triple tail. Here you have the Atlantic 5 miles off and go sword fishing that's why! We are the only place in the world to do all those things and it's a 100-mile stretch" 
The recreational fishing industry is a very important in many parts of the world. Specifically, in South Florida, it contributes a substantial amount to the economy. Without this industry, the broader economy as well as the people whose livelihoods depend on it will experience severe losses. The importance of understanding bonefish populations and why they have experienced declines is not only a benefit to the conservation and maintenance of the species, but also to the maintenance of livelihoods that recreational bonefish fisheries provide. By involving anglers and guides in the main data collection process we can increase both outreach and education on the importance of sustainable fishing practices and increase overall support for conservation. Continuous research about bonefish in South Florida and the integration of anglers and guides into the research process, would be very important in learning how to better manage this resource into in the future. 


\section{REFERENCES}

Abtew, W., \& Iricanin, N. (2008). Hurricane effects on South Florida water management system: A case study of Hurricane Wilma of October 2005. Journal of Spatial Hydrology, 8(1)

Ainsworth, C. H., Pitcher, T. J., \& Rotinsulu, C. (2008). Evidence of fishery depletions and shifting cognitive baselines in Eastern Indonesia. Biological Conservation, 141(3), 848-859.

Ault, J. s., Humston, R., Larkin, M. F., Perusquia, E., Farmer, N. A., Luo, J., et al. (2007). Population Dynamics and Resource Ecology of Atlantic Tarpon and Bonefish.

Ault, J. S., Bohnsack, J. A., Smith, S. G., \& Luo, J. (2005). Towards sustainable multispecies fisheries in the Florida, USA, coral reef ecosystem. Bulletin of Marine Science, 76(2), 595-622.

Beaudreau, A. H., \& Whitney, E. J. (2016). Historical patterns and drivers of spatial changes in recreational fishing activity in Puget Sound, Washington. PLoS one, 11(4), e0152190.

Beaudreau, A. H., \& Levin, P. S. (2014). Advancing the use of local ecological knowledge for assessing data-poor species in coastal ecosystems. Ecological Applications, 24(2), 244-256.

Berkes, F. (1993). Traditional ecological knowledge in perspective. Traditional ecological knowledge: Concepts and cases, 1-9.

Berkes, F., Colding, J., \& Folke, C. (2000). Rediscovery of traditional ecological knowledge as adaptive management. Ecological applications, 10(5), 1251-1262.

Bernard, H. R. (2006). Research methods in anthropology: Qualitative and quantitative approaches. Rowman Altamira. 
Bohnsack, J. A. (1997). Consensus development and the use of marine reserves in the Florida Keys National Marine Sanctuary. Protected Areas in Resource-Based Economies: Sustaining Biodiversity \& Ecological Integrity, 66.

Close, C. H., \& Hall, G. B. (2006). A GIS-based protocol for the collection and use of local knowledge in fisheries management planning. Journal of environmental management, 78(4), 341-352.

Colella, M. A., Ruzicka, R. R., Kidney, J. A., Morrison, J. M., \& Brinkhuis, V. B. (2012). Cold-water event of January 2010 results in catastrophic benthic mortality on patch reefs in the Florida Keys. Coral Reefs, 31(2), 621-632.

Cook, G. S., \& Heinen, J. T. (2005). On the uncertain costs and tenuous benefits of Marine reserves: a case study of the Tortugas Ecological Reserve, South Florida, USA. Natural Areas Journal, 25(4), 390-396.

Cooke, S. J., Danylchuk, A. J., Danylchuk, S. E., Suski, C. D., \& Goldberg, T. L. (2006). Is catch-and release recreational angling compatible with no-take marine protected areas? Ocean and Coastal Management, 342-354.

Cooke, S. J., \& Phillip, D. P. (2004). Behavior and mortality of caught-and-released bonefish (Albula spp.) in Bahamian waters with implications for a sustainable recreational fishery. Biological Conservation, 599-607.

Crabtree, R. E., Harnden, C. W., Snodgrass, D., \& Stevens, C. (1996). Age, growth, and mortality of bonefish, Albula vulpes, from the waters of the Florida Keys. Florida Marine Research Institute, 442-451.

Dallas, L., Shultz, A., Moody, A., Solman, K., \& Danylchuk, A. (2010). Chemical excretions of angled bonefish Albula vulpes and their potential use as predation cues by juvenile lemon sharks Negaprion brevirotris. Journal of Fish Biology, 947-962.

Danylchuk, A., Daynylchuk, S., Cooke, S., Goldberg, T., Koppelman, J., \& Phillip, D. (2007)a. Post-release mortality of bonefish, Albula vulpes, exposed to different handling practives during catch-and-release angling in Eleuthera, The Bahamas. Fisheries Management and Ecology, 149-154. 
Danylchuk, S. E., Danylchuk, A. J., Cooke, S. J., Goldberg, T. L., Koppelman, J., \& Phillip, D. P. (2007)b. Effects of recreational angling on the post release behavior and predation of bonefish (Albula Vulpes): The role of equilibrium status at the time of release. Journal of Experimental Marine Biology and Ecology, 127-133.

Daw, T. M. (2008). Spatial distribution of effort by artisanal fishers: Exploring economic factors affecting the lobster fisheries of the Corn Islands, Nicaragua. Fisheries Research, 90(1), 17-25.

Daw, T. M., Robinson, J. A. N., \& Graham, N. A. (2011). Perceptions of trends in Seychelles artisanal trap fisheries: comparing catch monitoring, underwater visual census and fishers' knowledge. Environmental Conservation, 38(01), 75-88.

Dongol, Y., \& Heinen, J. T. (2012). Pitfalls of CITES implementation in Nepal: a policy gap analysis. Environmental management, 50(2), 181-190.

Fernandez, C., \& Adams, A. J. (2004). Fly-fishing for bonefish. Stackpole Books.

Florida Keys National Marine Sanctuary and Protection Act. United States. Cong. National Marine Sanctuaries. 101st Cong., 2nd sess. Cong H.R. 5909. Vol. 104.U.S. Government Printing Office, 1990. <https:/www.gpo.gov/fdsys/pkg/STATUTE104/pdf/STATUTE-104-Pg3089.pdf

Fourqurean, J. W., \& Robblee, M. B. (1999). Florida Bay: a history of recent ecological changes. Estuaries, 22(2), 345-357.

Grant, S., \& Berkes, F. (2007). Fisher knowledge as expert system: A case from the longline fishery of Grenada, the Eastern Caribbean. Fisheries Research, 84(2), 162-170.

Haedrich, R. L., \& Barnes, S. M. (1997). Changes over time of the size structure in an exploited shelf fish community. Fisheries Research, 31(3), 229-239.

Hall, G. B., \& Close, C. H. (2007). Local knowledge assessment for a small-scale fishery using geographic information systems. Fisheries Research, 83(1), 11-22. 
Halpern, B. S., Walbridge, S., Selkoe, K. A., Kappel, C. V., Micheli, F., D'Agrosa, C., ... $\&$ Fujita, R. (2008). A global map of human impact on marine ecosystems. Science, 319(5865), 948-952.

Heinen, J. T. 2012. International Trends in protected areas policy and management. InTech, Chapter 1 in: www.intechopen.com (doi 10.5772/50061). Global Issues and Trends in the Protection of Natural Areas. $18 \mathrm{pp}$.

Heinen, J.T. 1995. International Conservation Agreements. pp. 375-384 In Nierenberg, W.A. (ed). Encyclopedia of Environmental Biology (Volume 1). San Diego: Academic Press.

Heinen, J. T., \& Shrestha-Acharya, R. (2011). The non-timber forest products sector in Nepal: Emerging policy issues in plant conservation and utilization for sustainable development. Journal of Sustainable Forestry, 30(6), 543-563.

Heinen, J.T. and R.J. Shrivastava. 2009. A demographic and socio-economic analysis of conservation attitudes and awareness around Kaziranga National Park, Assam, India: Implications for conservation and development. Population and Environment 30(6):261274.

Huntington, H. P. (1998). Observations on the utility of the semi-directive interview for documenting traditional ecological knowledge. Arctic, 237-242.

Huntington, H. P. (2000). Using traditional ecological knowledge in science: methods and applications. Ecological applications, 10(5), 1270-1274.

Johannes, R. E. (Ed.). (1989). Traditional ecological knowledge: a collection of essays. IUCN.

Keller, B. D., \& Causey, B. D. (2005). Linkages between the Florida Keys national marine sanctuary and the south Florida ecosystem restoration initiative. Ocean \& coastal management, 48(11), 869-900. 
Larkin, M., Ault, J., Humston, R., \& Luo, J. (2010). A mail survey to estimate the fisher dynamics of southern Florida's bonefish charter fleet. Fisheries Management and Ecology, 1-8.

Lavides, M. N., Polunin, N. V., Stead, S. M., Tabaranza, D. G., Comeros, M. T., \& Dongallo, J. R. (2009). Finfish disappearances around Bohol, Philippines inferred from traditional ecological knowledge. Environmental Conservation, 36(03), 235-244.

Lee, Jessica A., "Drying Times: Integrating Citizen Science to Examine Survival of Florida Largemouth Bass in a Coastal Refuge Habitat" (2015). FIU Electronic Theses and Dissertations. Paper 1854. http://digitalcommons.fiu.edu/etd/1854

Light, S. S., \& Dineen, J. W. (1994). Water control in the Everglades: a historical perspective. Everglades: The ecosystem and its restoration, 5, 47-84.

Liston, S. E., Frezza, P. E., Robinson, M., \& Lorenz, J. J. (2013). Assessment of Benthic Fauna Communities on Florida Keys' Shallow Banks as an. Tavernier: Audobon Florida.

Lozano, A. J. G., \& Heinen, J. T. (2015). Identifying Drivers of Collective Action for the Co-management of Coastal Marine Fisheries in the Gulf of Nicoya, Costa Rica.

Environmental management, 1-11

McIvor, C. C., Ley, J. A., \& Bjork, R. D. (1994). Changes in Freshwater inflow from the Everglades to Florida bay including effects on Biota and Biotic Processes: A Review. Everglades:The Ecosystem and its Restoration , 117-146.

Moller, H., Berkes, F., Lyver, P. O. B., \& Kislalioglu, M. (2004). Combining science and traditional ecological knowledge: monitoring populations for co-management. Ecology and society, 9(3), 2.

National Oceanic and Atmospheric Administration. (2013). Sanctuary Marine Zones. Florida Keys National Marine Sanctuary.

NOAA. Florida Keys National Marine Sanctuary, Final management plan/environmental impact statement, vol. 1. Silver Spring, MD: NOAA, 1996. 
Olsson, P., \& Folke, C. (2001). Local ecological knowledge and institutional dynamics for ecosystem management: a study of Lake Racken watershed, Sweden. Ecosystems, $4(2), 85-104$.

Porter, J. (Ed.). (2001). The Everglades, Florida Bay, and coral reefs of the Florida Keys: an ecosystem sourcebook. CRC Press.

Post, J. R., Sullivan, M., Cox, S., Lester, N. P., Walters, C. J., Parkinson, E. A., ... \& Shuter, B. J. (2002). Canada's recreational fisheries: the invisible collapse?. Fisheries, $27(1), 6-17$.

Prato, T. (2011). Adaptively managing wildlife for climate change: a fuzzy logic approach. Environmental management, 48(1), 142-149.

Ramos, J., Lino, P. G., Caetano, M., Pereira, F., Gaspar, M., \& dos Santos, M. N. (2015). Perceived impact of offshore aquaculture area on small-scale fisheries: A fuzzy logic model approach. Fisheries Research, 170, 217-227.

Saenz-Arroyo, A., Roberts, C., Torre, J., Cariño-Olvera, M., \& Enríquez-Andrade, R. (2005). Rapidly shifting environmental baselines among fishers of the Gulf of California. Proceedings of the Royal Society of London B: Biological Sciences, 272(1575), 1957 1962.

Stabenau E, K Kotun 2012. Salinity and hydrology of Florida Bay: status and trends 1990-2009.National Park Service, Everglades National Park, South Florida Natural Resources Center,Homestead, Fl. SFNRC Technical Series 2012:1.

Suman, D., Shivlani, M., \& Milon, J. W. (1999). Perceptions and attitudes regarding marine reserves: a comparison of stakeholder groups in the Florida Keys National Marine Sanctuary. Ocean \& Coastal Management, 42(12), 1019-1040.

Szekeres, P., Brownscombe, J. W., Cull, F., Danylchuk, A. J., Shultz, A. D., Murchie, K. J., et al. (2014). Physiological and behavioural consequences of cold shock on bonefish(Albula vulpes) in The Bahamas. Journal of Experimental Marine Biology and Ecology, 1-7. 
Teh, L. C., \& Teh, L. S. (2011). A fuzzy logic approach to marine spatial management. Environmental management, 47(4), 536-545.

Ter-Ghazaryan, D. and J.T. Heinen. 2006. Reserve management during transition: The case of Issyk-kul Strict Nature and Biosphere Reserve, Kyrgyzstan. Environmental Practice 8(1):11-22.

Thornton, T. F., Moss, M. L., Butler, V. L., Hebert, J., \& Funk, F. (2010). Local and Traditional Knowledge and the Historical Ecology of Pacific Herring in Alaska. Journal of Ecological Anthropology, 14(1), 81-88.

U.S. Department of Commerce. (1996).Final Management Plan/Environmental Impact Statement. Florida Keys National Marine Sanctuary,1-319.

Vasquez-Yeomans, L., Sosa-Cordero, E., Lara, M. R., Adams, A. J., \& Cohuo, J. A. (2009). Patterns of distribution and abundance of bonefish larvae Albula spp. (Albulidae) in the western Caribbean and adjacent areas. Ichthyological Research.

Zadeh, L. A. (1988). Fuzzy logic. Computer, (4), 83-93. Zadeh, L. A. (1988). Fuzzy logic. Computer, (4), 83-93.

Zadeh, L. A. (1965). Fuzzy sets. Information and control, 8(3), 338-353. 


\section{APPENDIX}

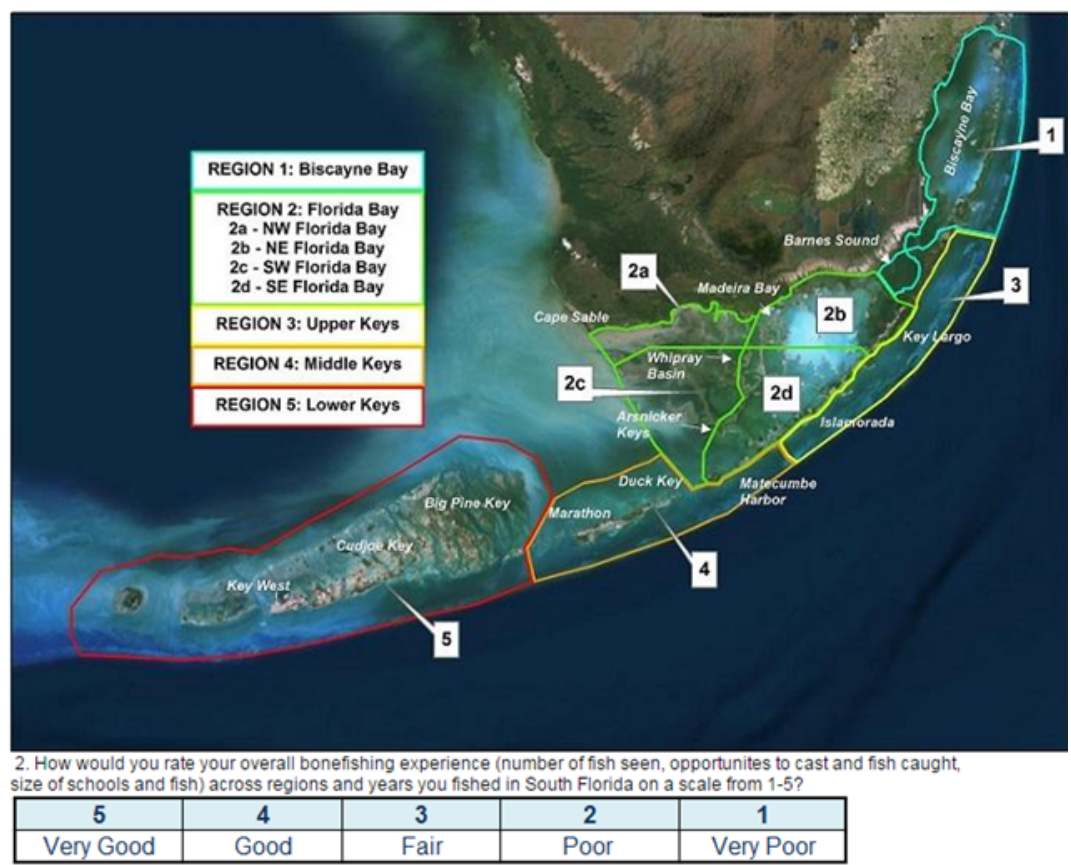

The map shows all regions for reference (leave regions and years you did not fish blank). Click map to enlarge as needed.

\begin{tabular}{l|lll} 
& Today (2014/2015) & 5years ago & 10 years ago \\
\hline Region 1: Biscayne Bay & \\
Region 2a: NW FL Bay & \\
Region 2b: NE FL Bay & \\
Region 2c: SW FL Bay & \\
Region 2d: SE FL Bay & \\
Region 3: Upper Keys &
\end{tabular}

Figure 1A. Example of matrix formatted question for a respondent that reported to have had 15 years of bonefishing experience in South Florida 


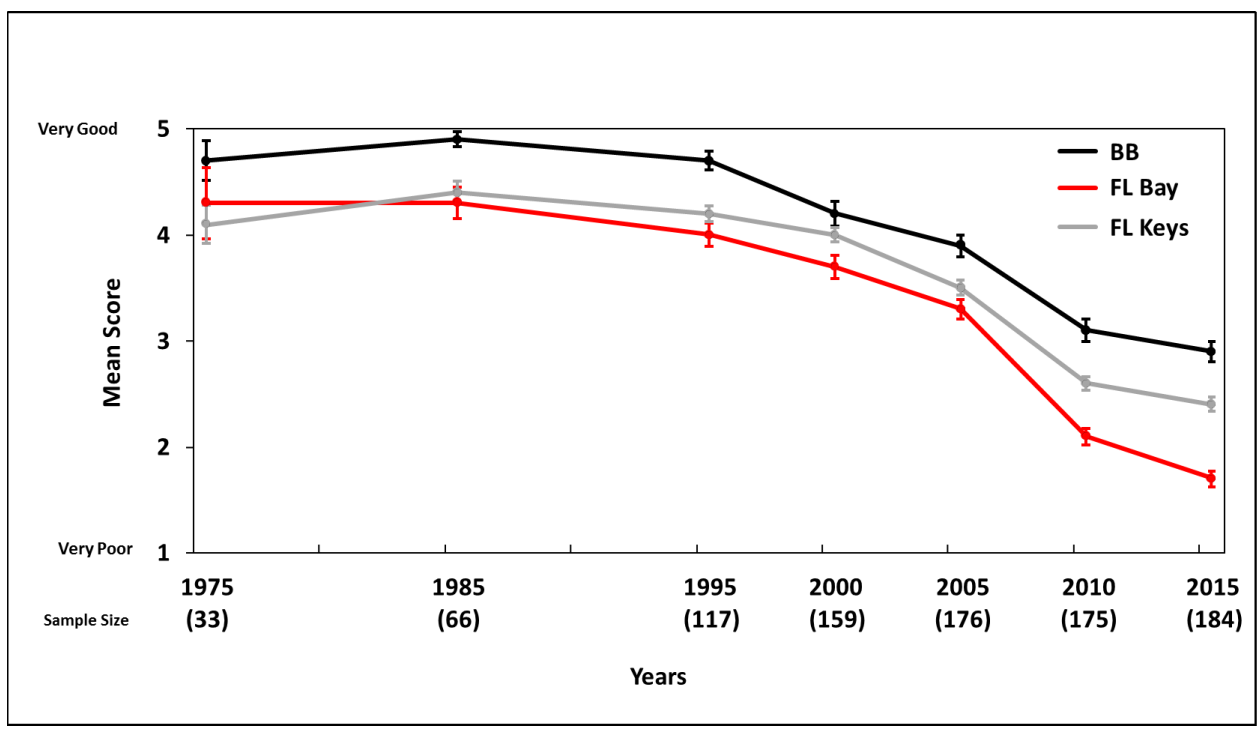

Figure 2A. Trend of bonefish decline is plotted from the mean scores rated by respondents on the overall quality of the bonefish fishery from 1975 to 2015 . The decline trend is separated into 3 major bonefishing regions in South Florida; Biscayne Bay (BB), Florida Bay (FL Bay) and Florida Keys (FL Keys). Respondents were asked to rate their bonefish fishing experience from 1-5 over the time they have been fishing for bonefish in South Florida. Sample size in the figure is based on the respondent sample size however; the trend is based on total response sample size. See methods for further explanation.

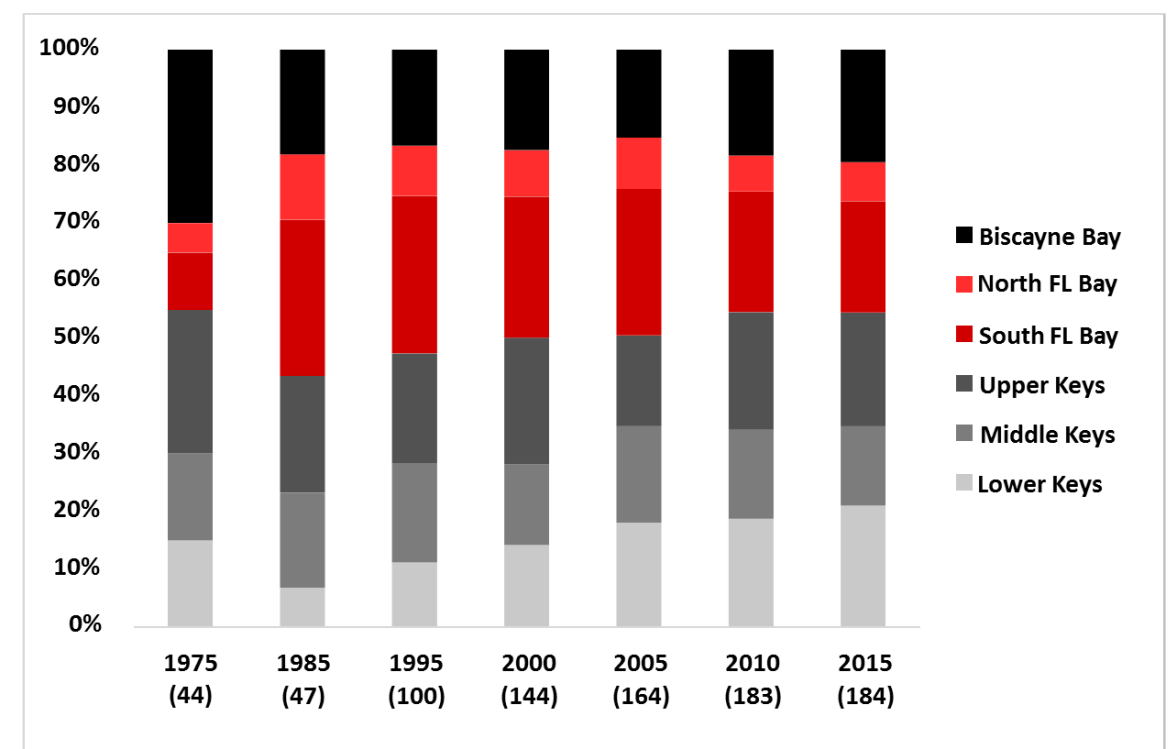

Figure 3A. Shifts in fishing effort of 6 regions in South Florida from 1975 to 2015. Fishing effort is calculated from the percentage of fishers that reported to have fished in each of the 6 regions from 1975-2015. Numbers in parenthesis are sample size of each time period. 
Table 1A. General information about the key informants interviewed and their reported observations of years they noticed bonefish decline $(\mathrm{N}=20)$.

\begin{tabular}{llc}
\hline \hline Parameter & Level & $\%$ \\
\hline Fisher Type & Guide & $65 \%$ \\
& Angler & $35 \%$ \\
\hline Experience & $1950 \mathrm{~s}$ & $15 \%$ \\
& $1960 \mathrm{~s}$ & na \\
& $1970 \mathrm{~s}$ & $45 \%$ \\
& $1980 \mathrm{~s}$ & $30 \%$ \\
& $1990 \mathrm{~s}$ & $\mathrm{na}$ \\
& $2000 \mathrm{~s}$ & $10 \%$ \\
\hline Observed decline & $1975-1989$ & $10 \%$ \\
& $1990-2005$ & $45 \%$ \\
& $2006-2015$ & $25 \%$ \\
& No response & $20 \%$ \\
\hline
\end{tabular}

